\title{
Malaria and Miscarriage in Ancient Rome $^{1}$
}

\author{
JOAN STIVALA
}

\begin{abstract}
Many Roman authors have claimed that induced abortions were frequent among aristocratic women in their society. They assumed that abortion was a simple procedure, easy to perform, and generally harmless for the women involved. The truth of these claims is frequently accepted by modern scholars. This article will argue that most supposed "abortions" were miscarriages caused by various infectious diseases, especially malaria.
\end{abstract}

Keywords. Rome, abortion, malaria, miscarriage

Résumé. Beaucoup d'auteurs romains ont affirmé que les avortements provoqués étaient fréquents parmi les femmes aristocratiques de leur société. Ils supposaient que l'avortement était une simple procédure, facile à réaliser, et généralement inoffensive pour les femmes impliquées. La vérité de ces affirmations est généralement acceptée par les spécialistes modernes. Cet article soutiendra que la plupart des supposés « avortements » étaient des fausses-couches causées par diverses maladies infectieuses, particulièrement la malaria.

Mots-clés. Rome, avortement, malaria, fausse-couche

Malaria has had profound demographic effects throughout history. In Mediterranean countries it has in the past led to the abandonment of fertile agricultural lands. ${ }^{2}$ It has also forced urban populations to desert their homes in a malarial area and re-establish their town in a healthier location. ${ }^{3}$ There are other, less immediately dramatic, effects on demography in the skewing of age distribution in a population exposed to the ravages of malaria. ${ }^{4}$ This article discusses one such demographic effect of malaria. It deals with miscarriage in the ancient Roman world. It will attempt to explain why the high rate of abortion claimed by contemporary authors was probably a reality, rather than the product of a fevered

Dr. Joan Stivala, Classics and Ancient History, Australian National University 
imagination. Given the nature of the evidence currently available much of this discussion is speculative.

Sallares notes that interest in malaria in the ancient Classical world declined after the eradication of malaria from Italy after the Second World War. ${ }^{5}$ This interest, however, did not disappear. Brunt devotes 14 pages to malaria in his Italian Manpower 225 B.C-A.D. $14 .{ }^{6}$ Scheidel offers a demographic perspective, ${ }^{7}$ and Shaw challenges the importance of malaria as a significant cause of death in Italy. ${ }^{8}$ Sallares' work revived my interest in malaria and its effect on the population of the Roman Empire. There has been no discussion that I have been able to find on the possible effects of malarial infection on the population sub-set that is the focus of this article-pregnant women.

When censorious senatorial writers condemned the large number of abortions among women of high status they were reporting a real phenomenon rather than reacting with moral panic to an imaginary problem. ${ }^{9}$ Their error lay in assuming that these abortions were induced. I argue that in fact most were spontaneous abortions, often caused by various diseases. One such disease was and is malaria, the subject of this article. The effects of malaria in pregnancy were first recognised only in the 1920s and 1930s. ${ }^{10}$

Enough contemporary witnesses as well as later commentators tell us that induced abortions were commonplace among aristocratic Roman women. There is not much childbirth in wealthy beds, according to Juvenal, because of the skills and the drugs of the abortionist:

sed iacet aurato uix ulla puerpera lecto.

tantum artes huius, tantum medicamina possunt,

quae steriles facit atque homines in uentre necandos

conducit.

-Juvenal, Satires 6.594-7.11

There are many references to abortion in Graeco-Roman literature. Most genres are represented-poetry, ${ }^{12}$ history and biography, ${ }^{13}$ as well as scientific $^{14}$ and medical works. ${ }^{15}$ The procedure is made to seem easy and simple: Pliny the Elder, for example, writes that abortion can be caused by the smell of lamps being extinguished; ${ }^{16}$ Soranus, who wrote on gynaecology in the second century A.D., provides an extensive list of methods of abortion from which a woman could choose if she wished to end a pregnancy. ${ }^{17}$

Many modern commentators accept the proposition that induced abortions were frequent, at least among the elite groups, and that there were effective and safe methods available. Kapparis, for example, concludes that some ancient methods for procuring abortion must have been effective, otherwise they would not have been preserved "in the most advanced medical handbooks" for two thousand years. ${ }^{18}$ The 
sheer number of methods recommended should give rise to the suspicion that many, if not most, were useless. No doubt physicians or midwives had their favourite method(s) which they believed to be reliable. For the woman attempting to end a pregnancy in secret and without medical advice the number of methods suggested must have made a decision very difficult indeed. It is possible that, as Kapparis suggests, various methods were tried serially, beginning with the most benign. ${ }^{19}$ One problem with this strategy is that there is a limited time in which to act and many methods to try. The long term survival of a treatment also does not always guarantee its efficacy. Another medical treatmentthe practice of venesection-also endured for two thousand years and more but was usually ineffective and often positively dangerous. There is no evidence that the loss of blood is therapeutic except in less than a handful of conditions.

\section{MISCARRIAGE}

In addition to unintended abortions caused by known or at least suspected factors such as accident or disease, there is an underlying rate of spontaneous abortion whose causes are largely unknown. These spontaneous abortions are usually termed "miscarriages." In modern general use the word "abortion" tends to imply that the foetal loss is deliberate, ${ }^{20}$ even when qualified by "spontaneous." For this reason "miscarriage" is the preferred term in this discussion to describe the unintended loss of a foetus, regardless of the cause(s). ${ }^{21}$ The underlying rate of miscarriage is about $15-20 \%$ of recognised pregnancies; of these up to $80 \%$ occur within the first trimester. ${ }^{22}$ Medical science now believes that in many cases a miscarriage constitutes the loss of a non-viable embryo. ${ }^{23}$ Although there are recognised medical causes of miscarriage the reasons for the majority remain a mystery. Some chronic conditions are known to be a threat to a pregnancy: diabetes, including gestational diabetes, hormonal imbalances, kidney disease, and cervical incompetence to name a few. There was little knowledge in the ancient world of these medical problems and their effects on pregnancy were not understood in the way they are now. Various infections can also result in miscarriage, including malaria, along with listeriosis, toxoplasmosis, and rubella, among others.

There is no reason to believe that miscarriages caused by these conditions were less frequent in the ancient world that they are now. Such miscarriages usually occur very early in gestation, often before the woman herself realises that she is pregnant. In the ancient world it is probable that nobody outside the woman's own household would have known that she had been pregnant, let alone that she had suffered a miscarriage. If a miscarriage of this nature occurred shortly after 
an abortifacient had been used it would be taken as evidence that the method had worked. This underlying rate of miscarriage is high enough to make the chance of such a coincidence reasonably high. Since it had apparently succeeded, that particular method of inducing an abortion could then enter folklore-and medical handbooks. ${ }^{24}$

Some discussion about ancient opinions on miscarriage is necessary in order to understand what appears to have been a commonly held view of the causes of miscarriage, that is, that it was caused by something the pregnant woman had done, whether deliberately or accidentally. ${ }^{25}$ This investigation will use the gynaecological work of Soranus as a guide to contemporary opinion on abortion and miscarriage. Soranus was a physician who practised in Rome in the early decades of the second century and whose medicine was based on Methodist doctrine. ${ }^{26}$ The Methodist system of medical practice arrived in Rome at the beginning of the first century A.D ${ }^{27}$ where it flourished to such an extent that it became the most successful of the Greek medical schools. ${ }^{28}$

\section{SORANUS ON MISCARRIAGE}

Soranus recommended medical care throughout pregnancy. He divided the term of human gestation into three periods, but they are not equivalent to the modern system of division into trimesters. In Soranus' system each period had its own stage of care: in the first period, it is necessary to preserve the injected seed; in the second the concern is to alleviate symptoms, in the last it is to ensure the "perfection of the embryo." ${ }^{29}$ Soranus believed that it takes 30 to 40 days for the seed to become properly implanted, ${ }^{30}$ and during that time it is vulnerable to being dislodged. His first period is about one third of the length of the modern first trimester, when, according to modern knowledge, most miscarriages occur. According to Soranus' theory, any woman who miscarried after the fortieth day of gestation was open to the suspicion of having induced an abortion. ${ }^{31}$

Soranus' list of methods of abortion is the same as his list of activities that a woman must avoid if she wants to preserve a pregnancy. ${ }^{32}$ There appears to be no particular order in the list, no warning that some activities are more dangerous for the mother or the foetus than are others. The list is so extensive and so many of the supposed hazards it contains are part of normal daily life that it is difficult to imagine how women could have avoided all of them. These restrictions were to apply for at least the first 30 days after conception..$^{33}$ After this time it was considered safe for the woman to resume normal activities until she reached the third period of pregnancy.

The theory that there are activities that the mother-to-be must avoid if she wants to preserve the pregnancy was not confined to Soranus; it 
was shared by Pliny the Younger and probably members of his extended family also. In a letter to his grandfather-in-law, and in another on the same topic to his wife's aunt, Pliny relays the sad news of his wife's miscarriage. ${ }^{34}$ There is no suggestion that she had deliberately aborted the foetus. Being young and inexperienced she had not realised that she was pregnant, had failed to take proper precautions, and had done "some things" she should not have done. ${ }^{35}$ These were originally private letters describing a family tragedy and subsequently published for a wider readership. Pliny expects his readers to agree with the stated reason for his wife's miscarriage. Clearly he believed this was generally accepted knowledge. We are not told what his wife did that supposedly caused the miscarriage. Since neither she nor anyone else had recognised the pregnancy, the miscarriage must have occurred early. Although an early miscarriage, or abortion, is safer for the woman than a later one, Calpurnia's life had been in danger, according to her alarmed husband. ${ }^{36}$

Although admitting the possibility of miscarriage, Soranus gives the impression that it is unlikely to occur if his rules are followed. This impression is strengthened by his claim that if a pregnant woman wished to abort the foetus she should do the things he had warned against. And she must continue to do them for 30 days after conception, that is, for the length of time according to Soranus' system, when the seed is in danger of ejection. ${ }^{37}$ The implication is obvious: in Soranus' eyes a miscarriage is the responsibility of the woman who has not followed his advice. It is clear that Soranus was familiar with spontaneous abortions that is, miscarriages. Since there had to be a rational explanation he concluded that the pregnant woman must have done something to bring on a miscarriage. This theory seems to have been widely held if we can judge from the various methods of procuring an abortion that were recommended. Even if the pregnant woman breaks some or all of Soranus' rules, yet does not miscarry, the foetus is still harmed either physically or psychically, perhaps both..$^{38}$ Thus the birth attendant, whoever she or he might be, could disclaim responsibility for a stillbirth, or a damaged or short-lived newborn. Once again the problem lies with the mother who did not, and perhaps could not, follow the instructions well enough. The birth of a dead or a damaged baby, Soranus believed, was caused by the mother's failure to obey his instructions.

In order to preserve a pregnancy, according to Soranus, the woman must avoid any excess or change, whether physical or emotional. The seed is evacuated by fright, sorrow, sudden joy, and any severe mental upset; by vigorous exercise, forced detention of the breath, coughing, sneezing, blows and falls (especially on the hips), lifting heavy weights, leaping, sitting on hard sedan chairs, administration of drugs (unspecified), the application of pungent substances, like garlic or onions (or 
leeks, preserved meat, or fish), or anything that causes sneezing, want, indigestion, drunkenness, vomiting, or diarrhoea; by nosebleeds, other bleeds, (haemorrhoids, for example), relaxation due to a heating agent, like a hot bath; or by marked fevers, rigors, or cramps. In general, anything inducing a forcible movement should be avoided. ${ }^{39}$

The list is long and as Soranus himself admits, it is probably impossible to avoid all of these dangers. ${ }^{40}$ At the very end of the list, however, he does recognize that disease could cause miscarriage, since he advises pregnant women to avoid fevers, rigors, and cramps. These are all symptoms of malarial infection, as well as of other infectious diseases. ${ }^{41}$ This information refers to one more danger among many others that the expectant mother must avoid.

The Hippocratic corpus contains references to the hazards that disease can pose to a pregnancy. ${ }^{42}$ Some Roman medical writers also recognised the risk of acute diseases to pregnant women. Celsus reports that "a woman ... when pregnant is easily carried off by an acute disease"; ${ }^{43}$ "even dysenteries are not a danger ... as long as fever and other accessories of this malady are absent, so that even a pregnant woman can not only be preserved, but the foetus preserved also"; 44 "diarrhoea is dangerous especially if accompanied by fever and other symptoms such as excessive thirst and especially if it becomes dysentery"; 4 "the disease is especially dangerous for children under the age of ten-and pregnant women who may survive but miscarry the child"; 46 and "in a pregnant woman immoderate looseness of the bowels can drive out the foetus." ${ }^{47}$ This description fits typhoid, but not malaria, since diarrhoea is not a symptom of malaria.

\section{ROMAN WRITERS ON ABORTION}

Ovid implies that abortions are commonplace among upper-class women; ${ }^{48}$ Seneca hints at the same. ${ }^{49}$ Juvenal, ${ }^{50}$ Ovid and Seneca claim, or imply, that many, possibly most, upper-class women have abortions, some of them more than once. Kapparis seems to assume that abortion was safe and easy in the ancient world. ${ }^{51}$ Ovid, Pliny, and Suetonius know better. Ovid fears for Corinna's life, Pliny claims that Calpurnia's life had been endangered despite the fact that the miscarriage had occurred early, Pliny and Suetonius report that Domitian's niece had died as the result of an abortion..$^{52}$

\section{ANCIENT METHODS OF ABORTION}

There can be little doubt that some women procured abortions, whether with assistance or self-induced, or at least attempted to do so. A valuable slave, for example, might be unable to perform her duties while 
pregnant..$^{53}$ The great majority of the suggested methods of inducing an abortion are known today to be ineffective: Pliny's lamps being extinguished, Soranus' hot baths, sitting on hard chairs, sneezing, and so on, although blows and heavy falls remain potentially dangerous for both mother and foetus. Ancient texts recommend hundreds of pharmacological agents for both contraception and abortion. ${ }^{54}$ Thus far I have found no evidence to challenge Prioreschi's conclusion that "the ancient physician did not have at his [or her] disposal effective ... abortifacient[s]." ${ }^{\prime 5}$ He recognized that a handful of the agents recommended did possess contraceptive/abortifacient properties, ${ }^{56}$ but the number of possibly effective plants recommended is lost in the static of the ineffective. It would have been sheer luck if the right one were chosen. Then there are the complications of preparation, dose, and application. A drug that is properly prepared and given in the right dose is unlikely to work if it is applied externally when it ought to be ingested. ${ }^{57}$

Farnsworth et al have written on the use of plants as abortifacients. ${ }^{58}$ Of the 565 species listed as having a reputation in folklore of being abortifacients, only 12 had, up to the time of publication of this review article, been shown to cause abortions in human beings; ${ }^{59}$ at least one (quinine) was unknown to Europe in the Roman period. ${ }^{60}$ Furthermore there is reason to doubt the ability of people in the ancient Mediterranean world to identify plants, even when lives depended on correct identification. The elder Pliny, for example, recorded that whole households and all the guests at banquets had been killed by eating poison mushrooms in mistake for edible varieties. ${ }^{61} \mathrm{He}$ cites specifically Annaeus Serenus, the prefect of Nero's guard, along with his tribunes and centurions. Assuming hidden knowledge known only to women in the ancient world and now lost, as Riddle does, ${ }^{62}$ is no solution. It is possible that this was the case; nevertheless, some form of evidence is required.

Primitive surgical methods were dangerous, sometimes fatal for the woman, and were not always successful in terminating a pregnancy. There is evidence in medical works that methods of surgical termination were known. Although he does not recommend this procedure as a means of abortion, Celsus describes an operation to be performed to remove a dead foetus. ${ }^{63}$ He stresses that the operation is to be regarded as a last resort. ${ }^{64}$

Under the conditions obtaining in the ancient world, including the lack of sterile or antiseptic technique or an accurate knowledge of internal anatomy, to say nothing of the lack of effective anaesthesia, or even pain relief, the experience would have been horrific and probably fatal for the woman. It is unlikely that any woman would endure that experience except in a last desperate effort to save her life, unless she was certain that even death was preferable to continuing with the pregnancy. It is unimaginable that she would be prepared to undergo the procedure 
several times; doubtful even that she would be able to survive the first such procedure. ${ }^{65}$

If abortions were as common as some ancient works claim, and not a perception induced by some sort of moral panic, then there must be another explanation for their frequency. This article will suggest that most were spontaneous miscarriages rather than induced abortions. There are various bacterial and viral infections that can cause a pregnant woman to abort a foetus: some sexually transmitted diseases, rubella, and bacterial food poisoning, among others. These diseases, for which there was no effective treatment in antiquity, would have caused a high rate of miscarriage. Such diseases would have had the same effect among non-elite women, although senatorial critics would not have noticed, or cared.

\section{MALARIA IN THE MEDITERRANEAN}

This investigation concentrates on malaria, a disease that was endemic to the Mediterranean region during the Roman period when it was an area of unstable endemic malaria. In areas so named the population is more or less permanently exposed to malarial infection, but inoculation rates fluctuate. They tend to be low and erratic, leading to extended periods (six months to a year and even longer) without re-infection. Malaria in Mediterranean lands was also seasonal, ${ }^{66}$ the largest number of infections occurring in late July. ${ }^{67}$ This seasonal peak was noted in antiquity. ${ }^{68}$ These conditions left individuals vulnerable to active malarial infection since continued immunity against malaria is dependent on continual challenges which do not occur under these circumstances.

The frequency of miscarriage due to malaria increases with gestational age, with the highest rate occurring in the second and third trimesters-by modern reckoning - when acquired immunity tends to break down. Any immunity to the disease that a pregnant woman might have developed in the past was lost by infrequent inoculation or compromised by her pregnancy. If the disease caused a late-term miscarriage, it could well put her life in danger. If the woman were a Roman aristocrat she might well have been suspected of having induced the abortion. At about 29 weeks' gestation the pregnancy would almost certainly have been obvious, or at least suspected. Because she was long past Soranus' danger period of 30 to 40 days' gestation, many people in her society who agreed with his obstetrical system would have believed that a miscarriage at such a late period could not have happened accidentally. 
Human malaria is caused by five species of the Plasmodium genus. Three of these species were responsible for malarial infections in ancient Greece and Rome: Plasmodium falciparum and Plasmodium vivax, the species responsible for most human infections, ${ }^{69}$ and Plasmodium malariae. $P$. falciparum causes the most serious complications, including the severe and often fatal "subtertian malignant" fever. ${ }^{70} P$. vivax causes "benign tertian" fevers (recurring every second day); P. malariae causes "quartan" fever (recurring every third day). ${ }^{71}$

Malarial parasites require specific species of mosquitoes to complete their life-cycle and also to transmit them to and from a suitable vertebrate host. The plasmodial life-cycle is complex and the anopheline mosquitoes are the obligatory intermediary host and vector. There are three main vectors of human malaria in Europe: Anopheles labranchiae, A. acharovi and A. atroparvus. All three can breed in both fresh and brackish water. ${ }^{72} \mathrm{~A}$ brief, and necessarily simplified, description of the parasite's complicated life-cycle may be useful here.

A female mosquito bites an infected human, ingesting Plasmodium gametocytes which initiate sexual reproduction in the insect's stomach. ${ }^{73}$ The resulting zygote encysts on the outer surface of the wall of the stomach. Asexual division within this cyst results in the production of large numbers of sporozytes which migrate to the salivary glands to be injected into a vertebrate host when the insect next feeds. ${ }^{74}$

In the vertebrate host asexual reproduction occurs first in the liver; this stage is asymptomatic. ${ }^{75}$ Asexual reproduction occurs next in the red blood cells of the host. The resulting parasite development, in conjunction with the accompanying rupture of the red cells, causes the intermittent fevers characteristic of malaria. The parasites then produce sexual gametocytes within the red cells, and the cycle continues when a mosquito feeds on the infected vertebrate host.

\section{SYMPTOMS OF MALARIA}

The symptoms of malaria differ according to which Plamodium species is involved: P. vivax infections are characterised by relapses, sometimes months after the original infection. ${ }^{76} P$. malariae does not cause relapses but can cause chronic, subclinical infections that persist for years, ${ }^{77}$ while $P$. falciparum malaria commonly causes the severe and life-threatening dysfunction of vital organs-lungs, kidneys, liver, brain. Malarial infection in the brain is referred to as cerebral malaria ${ }^{78}$ All three species cause the characteristic febrile episodes accompanied by regular periodic paroxysms with chills, rigors, and sweating. ${ }^{79}$ 
Malarial infections share many symptoms with other infectious illnesses, symptoms such as body aches, headache, nausea, and general weakness ${ }^{80}$ To complicate the problems of diagnosis even further symptoms are often non-specific and can be mistaken for other conditions like influenza, septicaemia, gastroenteritis, and viral infections. ${ }^{81}$

\section{IMMUNITY AGAINST MALARIA}

Infection by malaria in pregnant women who have already had several pregnancies can present insidiously with little sign of the infection, ${ }^{82}$ but "all pregnant women from non-endemic settings are at increased risk of severe malaria and potentially severe consequences for them and their pregnancy." ${ }^{13}$ There are two types of immunity against malaria, acquired and innate. Both of these mechanisms can prevent the more severe manifestations of malarial infection, including death; neither, however, can usually eliminate the infection. ${ }^{84}$ Often a low-grade parasitaemia remains and may persist for years..$^{85}$

Acquired immunity does not protect an individual from infection with malaria, but it does offer protection from the worst symptoms. Individuals suffering from asymptomatic malarial infection would not have been identified in the ancient world. These people also provide a reservoir of Plasmodium parasites. The number of malaria inoculations and the intervals between them are all-important in developing and maintaining immunity. ${ }^{86}$ One or two acute attacks of Plasmodium falciparum may confer some immunity against severe and life-threatening disease; other, non-life-threatening effects require a larger number of inoculations occurring more frequently. ${ }^{87}$ Effective immunity is conferred only by very many and frequent infections. This acquired immunity is species specific and is moreover effective only against local strains. ${ }^{88}$ If a person who has acquired immunity to malaria in one area moves to another area with different strains of malaria, immunity must be developed to those specific strains. Immunity, moreover, is readily lost; a period of six to twelve months without re-infection seems to be long enough. ${ }^{89}$

In contrast to acquired immunity, innate immunity appears to limit the growth of all blood-stage Plasmodia species and strains. ${ }^{90}$ People carrying one of the mutations that protect against malaria do not have to be immunized by infection. Genetic or innate immunity against malaria has evolved in populations exposed to infection over a long period of time. ${ }^{91}$ This immunity is due to genetic polymorphisms that affect the red blood cells. They include the thalassaemia anaemias, which occur at elevated frequencies around the shores of the Mediterranean and elsewhere, including the Middle East and most of Africa. A group of mutations in the sex-linked gene for glucose-6-phosphate dehydrogenase (G6PD) has a similar geographical distribution. Neither of these 
traits is highly protective against falciparum malaria, although both appear to reduce the risk of death by about $50 \%$. Other mutations like haemoglobin $\mathrm{S}$ which causes sickling of the red cells, confer at least $90 \%$ protection against mortality from malarial infection. ${ }^{92}$ This trait is found in high frequencies in populations in parts of the southern and eastern Mediterranean, especially in Greece. A carrier population of the sickle-cell mutation pays a high price for protection against $P$. falciparum malaria. Modern studies in parts of Africa, where the frequency of the sickle-cell gene exceeds $30 \%$, have shown that at least $10 \%$ of babies are born homozygous for this trait. ${ }^{93}$ Such individuals would probably not have survived to puberty in the ancient world. ${ }^{94}$ How prevalent any of these traits were in Roman times is an avenue to be explored.

\section{PROTECTION AGAINST MOSQUITOES}

Neither the Greeks nor the Romans recognised the mosquito's role in transmitting disease. But they did regard them as troublesome pests and sought to protect themselves.

There were various methods available to kill or repel mosquitoes as well as various other annoying insects. Pliny recommends burning coriander to kill culices and muscae. ${ }^{95} \mathrm{He}$ also recommends burning lupins, the rind of wild pomegranates, or wormwood to kill culices. ${ }^{96}$ There is no doubt that the word culices includes mosquitoes ${ }^{97} \mathrm{He}$ has a recipe for an insect repellent made of wormwood mixed in oil to be smeared on the skin. ${ }^{98}$ Wormwood, at least, may have been effective. Modern experiments have shown that wormwood can kill mosquitoes in a closed chamber within 24 hours. ${ }^{99}$ Unfortunately Celli, who was responsible for this research, makes no mention of how large the space was or how much wormwood was required. There are similar problems with Pliny's personal repellent: how concentrated did the wormwood have to be? Pliny does not provide this information-another example of a method that might have worked but we do not know whether it did because we do not know exactly how it was prepared or used.

As well as repelling or killing mosquitoes methods of avoidance were used by people in the Roman Empire. One method is to live in an area known, or believed, to be free from malaria. Varro and Vitruvius recommended building on elevated ground rather than in a hollow. ${ }^{100}$ Columella advised against siting farm buildings near a marsh, and specifically mentions stinging insects ("... aculeis armata gignit animalia ..."). ${ }^{101}$ Pliny the Elder also advised against building near marshes or a river. ${ }^{102}$ Ironically, wealthy Romans, having taken pains to site their houses in healthy locations, then invited mosquitoes inside by providing them with places to rest and to breed in the impluvium and a well-watered garden. ${ }^{103}$ 
Another method to avoid insect bites at night is by using a mosquito net. The Romans had such a net, a conopium or conopeum. Nets do have some drawbacks since they must be kept in good repair and tucked in so that the sleeper does not dislodge them during the night. In hot and humid weather the user can feel that there is insufficient air-flow for comfort, with the resulting temptation to cast the net aside. ${ }^{104}$ Modern research has demonstrated that nets are most effective if treated with insect repellent, although no evidence suggests that Romans treated theirs. ${ }^{105}$ Untreated nets, however, although not as effective as those that have been treated, are still better than no net. ${ }^{106}$

\section{MALARIA IN PREGNANCY}

A modern case study illustrates the points on loss of immunity and the seriousness of malaria in pregnancy; it presents an unusual combination of 21st-century medical care side-by-side with conditions not too far removed from those that prevailed in the ancient world. In 2005 a pregnant woman presented at a hospital casualty department in Georgia, US. Born in Sierra Leone, she had been resident in the US for 16 years, from the age of $20 .{ }^{107}$ She was about 29 weeks pregnant with her third child. Some 10 weeks previously, at about 19 weeks' gestation, she had made an urgent trip to Sierra Leone. A routine obstetrical check-up shortly before her departure showed normal foetal development. She took no anti-malarial medication before leaving the US and no special precautions to guard against infection during her more than eight weeks' stay in Sierra Leone. An obstetrical examination on her return to the US showed that foetal development appeared to be normal.

Within a week of her return from Africa she developed symptoms that were serious enough to force her to seek medical advice. Doctors in the casualty department diagnosed infection due to Plasmodium falciparum. The patient was admitted and treated with a combination of anti-malarial drugs known to be safe in pregnancy. Three days after admission she miscarried; four days later she was well enough to be discharged. During her stay in a non-malarial area the patient had lost whatever immunity she had developed while growing up in a malarial area. Worried about its effect on the developing foetus she had taken no anti-malarial medication before departure or during her stay in Sierra Leone. She took no special precautions to protect herself against malaria while in Africa. Two obstetrical examinations in an advanced health system showed normal foetal development; a third, while the mother was showing symptoms of malarial infection, indicated that the foetus was still alive. Medical treatment in an advanced health system was unable to save the pregnancy but possibly saved the mother's life. 
As the above example demonstrates, malaria causes serious complications in pegnancy. All species of the malaria parasite are dangerous and the risk of malarial infection in pregnancy is high, even for women who have developed good immunity. Complications due to malarial infection include high rates of maternal mortality, stillbirth, and premature birth. ${ }^{108}$ The incidence of malaria increases during pregnancy, ${ }^{108}$ while the frequency and severity of malarial infection are greater during pregnancy in comparison both with the same immune woman when she is not pregnant and with other immune women who are not pregnant. ${ }^{110}$ Non-immune pregnant women are at higher risk of foetal loss. In areas of endemic malaria, when women have acquired immunity during childhood, the effects are less marked, but women with some immunity lose part of this protection when pregnant, especially in the first pregnancy. ${ }^{111}$ Acquired immunity to infection by $P$. falciparum tends to break down in the second and third trimesters.

Malaria can cause an abortion rate as high as 50\% if the woman exhibits symptoms of malaria; asymptomatic malaria is responsible for an abortion rate of about $30 \%$. In the United States in the first half of the 20th century the rate of miscarriage attributed to maternal infection with $P$. falciparum has been estimated to have been as high as $60 \% .{ }^{112}$ During an epidemic of malaria (species unspecified) in Sri Lanka in 1934-1935 the fatality rate among pregnant women was 13\%, with a foetal loss or neonatal death rate of $67 \%$ at Colombo General Hospital. ${ }^{113}$ At Byumba District Hospital, Rwanda, during an epidemic in 1998, 71\% of maternal deaths were attributed to malarial infection. ${ }^{114}$

Most of the deleterious effects of malaria in pregnancy are thought to be due to placental malaria. Placental malaria in semi-immune women is often afebrile. ${ }^{115}$ In the context of the ancient world this means that in these cases the disease would not have been suspected. It is difficult enough to diagnose using modern laboratory methods. The placenta is severely affected by P. falciparum infection, especially in first pregnancies. Large numbers of plasmodia in the placenta is a frequent cause of miscarriage in non-immune women and of foetal anaemia and intrauterine growth retardation in those with some degree of immunity. This often results in low birth weight and infants with an increased susceptibility to other infections. ${ }^{116}$

Attacks of vivax malaria can bring an increased risk of miscarriage or stillbirth. ${ }^{117}$ P. vivax also causes birth weight reduction in all pregnancies, not only first pregnancies. ${ }^{118}$ This parasite has a dormant phase where there is little or no rupture of red cells; the sporozoites become hypnozoites and do not cause symptoms, although they may later be activated to cause clinical illness. ${ }^{119}$ A primary attack of vivax can cause seven or more relapses. Such relapses occurring in pregnancy carry the risk of miscarriage or stillbirth. ${ }^{120}$ 


\section{CONCLUSION}

Spontaneous abortions, miscarriages, were at least as frequent in the ancient world as they are now. The human body has not changed since the time of the Graeco-Roman Empire; its construction and its organs are still the same. ${ }^{121}$ Arguably they occurred at a much higher rate because of diseases that no longer present the same risk in at least some parts of the modern world.

If abortions were as frequent in the Roman world, as so many writers claim, then they were more likely to have been miscarriages rather than induced abortions. And it is probable that many of them were caused by malaria. Pregnant women are particularly susceptible to malarial infection during the second and third trimesters (using modern reckoning) of gestation, after the period that Soranus believed a miscarriage could occur. In his world any woman who miscarried so late in a pregnancy was likely to find herself suspected of having procured an abortion, either self-induced or with assistance from another. If the infection was afebrile the possibility of disease would not have been considered. With a possible maternal death rate of $50-60 \%$ and an even higher rate of miscarriage due to malarial infection it is not surprising that so many commentators believed that abortion was commonplace in their world.

\section{NOTES}

1 The substance of this article was presented in poster form at the 34th conference of the Australasian Society for Classical Studies held in Sydney, Australia in January 2013.

2 Hackett disputes the idea that malaria has been responsible for the depopulation of any long-established agricultural settlement on fertile soil. He suggests that the Pontine Marshes, for example, were deserted because of the destruction wrought by successive invading armies. He does concede that malaria prevented its successful re-occupation. See L. W. Hackett, Malaria in Europe: An Ecological Study (Oxford: Oxford University Press, 1937), xii. Sallares on the other hand, dates the collapse of the population in the Marshes to a time when the area was firmly under Roman control and believes that endemic malaria caused the evacuation of the surviving population See Robert Sallares, Malaria and Rome: A History of Malaria in Ancient Italy (Oxford: Oxford University Press, 2002), 186.

3 Pausanias, Description of Greece, trans. W. H. S. Jones, Loeb Classical Library, vol. 3 (Cambridge, Mass., 1933), 7.2.10-11; Pausanias, Guide to Greece, Volume 1: Central Greece, trans Peter Levi, (Hammondsworth: Penguin 1979), n. 10 on 232; Sallares, Malaria and Rome, 119. The translocation noted by Sallares did not occur in ancient times, but in 1253; it is used here as another example of the continuing effect of malaria on human settlement patterns.

4 Walter Scheidel, "Roman Age Structure: Evidence and Models," The Journal of Roman Studies 91 (2001): 8-9.

5 Sallares, Malaria and Rome, 4.

6 P. A. Brunt, Italian Manpower 225 B.C-A.D. 14 (Oxford, 1971), 611-24. 
7 Scheidel, "Roman Age Structure: Evidence and Models," 8-9; Walter Scheidel, "Libitina's Bitter Gains: Seasonal Mortality and Endemic Disease in the Ancient City of Rome," Ancient Society 25 (1994): 154, 155-57, 159-160.

8 Brent D. Shaw, "Seasons of Death: Aspects of Mortality in Imperial Rome," The Journal of Roman Studies 86 (1966): 132, 133.

9 This discussion is confined to aristocratic women as women of low status were invisible to commentators who were interested in condemning the habits of women of their own class.

10 Richard W. Steketee, Bernard L. Nahlen, Monica E. Parise, and Clara Menendez, "The Burden of Malaria in Pregnancy in Malaria Endemic Areas," American Journal of Tropical Medicine and Hygiene 64, no. 1, 2S (2001): 28; and Meghna Desai, Feiko O ter Kuile, François Nosten, Rose McGready, Kwame Asamoa, Bernard Brabin, and Robert D. Newman, "Epidemiology and Burden of Malaria in Pregnancy," The Lancet: Infectious Diseases 7 (February 2007): 93. http://infection.thelancet.com accessed December 2012.

11 "But how often does a gilded bed contain a woman that is lying in? So great is the skill, so powerful the drugs, of the abortionist, paid to murder mankind within the womb." Juvenal and Persius, trans. G. G. Ramsay, Loeb Classical Library (Cambridge, Mass: Harvard University Press, 1979), 131, 133. It was, and remains, better to avoid pregnancy altogether than to undergo an abortion. According to Juvenal, Roman noblewomen had slaves castrated at puberty so that they could take them as lovers without fear of pregnancy (Juvenal, Satires 6.366-378).

12 Ovid, Heroides.Amores, trans. Grant Showerman, revised G. P. Goold, Loeb Classical Library (Cambridge, Mass: Harvard University Press, 1977), Amores 2.13, 2.14; Juvenal, Sat. 2.34-40; 6.594-60, for example.

13 Tacitus, Annals, ed. C. D. Fisher (Oxford, 1966), 14.63; Suetonius, Domitian, trans. J. C. Rolfe, Loeb Classical Library, vol. 2 (London: William Heinemann, 1970), 22. Also note Seneca, Moral Essays, trans. John W. Basore, vol. 2, Loeb Classical Library (London: W. Heinemann, 1951), Ad Heluiam 16.3.

14 Pliny the Elder, Naturalis historia, trans. H. Rackham, vol. 2, Loeb Classical Library (London: Heinemann, 1939-1963).

15 Owsei Temkin, Soranus' Gynacology (Baltimore and London: Johns Hopkins University Press, 1956).

16 Pliny, HN 7.7.43.

17 Temkin, Soranus' Gynacology, 1.19.64, (p. 66-8).

18 Konstantinos Kapparis, Abortion in the Ancient World (London: Duckworth, 2002), 16.

19 Kapparis, Abortion in the Ancient World, 22.

20 Oxford English Dictionary, third edition, September 2009. http://www.oed.com/view/ Entry/503?redirectedFrom=abortion\# eid, accessed 21 January 2015.

21 Latin and ancient Greek lack words that mean specifically "miscarriage" or "abortion." There are several Latin nouns (abortion, abortus, abortum, for example) which are used for both abortion and miscarriage. The word must be qualified in some way or the context must make the meaning clear. Greek terms include ä $\mu \beta \lambda \omega \sigma \iota \varsigma$ (abortion/ miscarriage) and ả $\mu \beta \lambda i \sigma \kappa \omega$ (miscarry, cause a miscarriage/abortion). In Greek, the language of the Hippocratic corpus, of Soranus, and of many other medical practitioners, the subject of the verb or the context indicates whether the abortion is thought to have been spontaneous or induced.

22 Elizabeth E. Puscheck, "Early PregnancyLoss," eMedicine Obstetrics and Gynecology, 2, http://emedicine.medscape.com/article/266317, accessed 19 October 2010; Sarah Berry, "Women's Silent Suffering," The Sydney Morning Herald, 28 May 2012, 1, http:// www.smh.com.au/Article?id=333162, accessed 22 January 2015.

23 Berry, "Women's Silent Suffering," 1; Diseases and Conditions-Mayo Clinic: Miscarriage, 1-2, http://www.mayoclinic.org/diseases-conditions/pregnancy-loss -miscarriage/basics/def, accessed 22 January 2015. 
24 Burch, Taking the Medicine, 271.

25 The belief that women could deliberately, and successfully, abort a pregnancy can be traced as far back as the composition of the Hippocratic treatises. Epidemics 5.53 records the attending doctor's suspicion that the wife of Simus might have died as the result of a deliberate abortion. See Hippocrates, vol. 7, trans. Wesley D. Smith, Loeb Classical Library (Cambridge, Massachusetts: Harvard University Press, 1994). This case is repeated at Epidemics 7.74. Unfortunately the practitioner does not suggest what his patient might have taken, or why his suspicions were aroused. The example demonstrates a belief that some women had access to effective abortifacients.

26 I. E. Drabkin, "Soranus and his System of Medicine," Bulletin of the History of Medicine 25 (1951): 504.

27 Drabkin, "Soranus and his System of Medicine," 505.

28 Drabkin, "Soranus and his System of Medicine," 506, with note 1; Vivian Nutton, "Galen and Roman Medicine: Or Can a Greek become a Latin?" European Review 20, no. 4 (October 2012): 541, with note 15.

29 Temkin, Soranus' Gynacology, 1.14.46, (p. 45).

30 Temkin, Soranus' Gynacology, 1.19 .64 (p. 66).

31 It is not clear how the fortieth day of gestation was calculated.

32 Temkin, Soranus' Gynacology, 1.19.64-65 (p. 66-8); 1.14 .46 (p. 45-6).

33 Temkin, Soranus' Gynacology, 1.19 .64 (p. 66).

34 Pliny the Younger, Epistularum libri decem, ed. R. A. B. Mynors (Oxford, 1985), Epp. $8.10,11$.

35 "... quaedam custodienda praegnantibus omittit, facit omittenda..." (Pliny the Younger, Ep. 8.10).

36 Pliny the Younger, Ep. 8.10, 11.

37 Temkin, Soranus' Gynacology, 1.19 .64 (p. 66).

38 Temkin, Soranus' Gynacology, 1.14 .47 (p.48).

39 Temkin, Soranus' Gynacology, 1.14 .46 (p.45-46).

40 Temkin, Soranus' Gynacology, 1.14 .46 (p. 46).

41 Richard Carter and Kamini N. Mendis, "Evolutionary and Historical Aspects of the Burden of Malaria," Clinical Microbiology Reviews 15, no. 4 (October 2002): 566.

42 Hippocrates, Epidemics (Hippocrates Volume 7 ), 2.3.1d; 4.6, 7, 25; 7.41; Airs, Waters, Places, trans. J. Chadwick and W. N. Mann, in Hippocratic Writings, ed. G. E. R. Lloyd (Harmondsworth: Penguin, 1950), 3, 10; Aphorisms, trans. Chadwick and Mann , in Hippocratic Writings, 3.12; 5.55 .

43 "Mulier quoque grauida acuto morbo facile consumitur" (Celsus 2.6.8).

44 "Ac ne tormina quidem periculosa sunt ... dum febris ceteraeque accessiones huius morbi absint, adeo ut etiam grauida mulier non solum reseruari possit, sed etiam partum reseruare" (Celsus 2.8.13).

45 Celsus 2.8.30.

46 Celsus 2.8.30.

47 "Mulieri grauidae sine modo fusa aluus excutere partum potest" (Celsus 2.7.16).

48 Ovid, Amores 2.14

49 Seneca, Ad Heluiam 16.3.

50 Juvenal, Satire 2.34-40; Kapparis, Abortion in the Ancient World, 83.

51 Kapparis, Abortion in the Ancient World, 83.

52 Pliny, Ep. 4.11.16; Suetonius, Domitian 22.

53 Iain M. Lonie, The Hippocratic Treatises "On Generation", "On the Nature of the Child," "Diseases IV" (Berlin and New York: Walter de Gruyter, 1981); On the Nature of the Child, 131 (p. 7). In this case the young slave tells her owner that she fears she is pregnant; it is the owner who arranges medical advice on abortion. For an extended discussion see Kapparis, Abortion in the Ancient World, 111-12. 
54 Plinio Prioreschi, "Contraception and Abortion in the Ancient World," Vesalius: acta internationales historiae medicina, I.2 (1995): 81. Texts often do not differentiate between the two.

55 Prioreschi, "Contraception and Abortion in the Ancient World," 83.

56 Prioreschi, "Contraception and Abortion in the Ancient World," 81.

57 Druin Burch, Taking the Medicine, 21-2.

58 Norman R. Farnsworth, Audrey S. Bingel, Geoffrey A. Cordell, Frank A. Crane, and Harry H. S. Fong, "Potential Value of Plants as Sources of New Fertility Agents I," Journal of Pharmaceutical Sciences 64, no. 4 (April 1975): 535-98.

59 Farnsworth et al "Potential Value of Plants", Table IV, 583.

60 It should be noted that this review article covers many different traditions and periods.

61 Pliny, HN 22.47.96.

62 J. M. Riddle, Eve's Herbs: A History of Contraception and Abortion in the West (Cambridge, Mass: Harvard University Press, 1997).

63 Celsus 7.29

64 Celsus 7.29.1.

65 Kapparis, Abortion in the Ancient World, 27.

66 Sallares, Malaria and Rome, 61.

67 Sallares, Malaria and Rome, 62.

68 Sallares, Malaria and Rome, 61-3 (Columella, Vitruvius, Antyllus, Athenaios [p.61], Theophrastus [p. 62], pseudo-Aristotelian Problems, Hippocratic Aphorisms [p. 63]).

69 Behzad Nadjm and Ron H. Behrens, "Malaria: An Update for Physicians," Infectious Diseases Clinics of North America 26, no. 2 (2012): 243.

70 Carter and Mendis, "Evolutionary and Historical Aspects of the Burden of Malaria," 565; Lisa M. Hollier, April L. Ericksen, and Susan M. Cox, "Malaria in Pregnancy," Infectious Diseases in Obstetrics and Gynecology 5 (1997): 45.

71 The terms "tertian" and "quartan" were bestowed when inclusive counting was commonly used. This method of reckoning is no longer the norm, but the original terms have been retained.

72 Sallares, Malaria and Rome, 44.

73 Hollier et al, "Malaria in Pregnancy," 45.

74 Hollier et al, "Malaria in Pregnancy," 45.

75 Denise L. Doolan, Carlotta Dobaño and Kevin Baird, "Acquired Immunity to Malaria," Clinical Microbiology Reviews (Jan. 2009): 13.

76 Nadjm and Behrens, "Malaria," 245.

77 Nadjm and Behrens, "Malaria," 245.

78 Carter and Mendis, "Evolutionary and Historical Aspects of the Burden of Malaria," 566.

79 Carter and Mendis, "Evolutionary and Historical Aspects of the Burden of Malaria," 566.

80 Carter and Mendis, "Evolutionary and Historical Aspects of the Burden of Malaria," 566.

81 Nadjm and Behrens, "Malaria," 247.

82 Nadjm and Behrens, "Malaria," 255.

83 Nadjm and Behrens, "Malaria," 255.

84 Mary M. Stevenson and Eleanor M. Riley, "Innate Immunity to Malaria," Nature Reviews: Immunology 4 (March 2004): 169.

85 Stevenson and Riley, "Innate Immunity to Malaria," 169.

86 Carter and Mendis, "Evolutionary and Historical Aspects of the Burden of Malaria," 566.

87 Carter and Mendis, "Evolutionary and Historical Aspects of the Burden of Malaria," 566. 
88 Carter and Mendis, "Evolutionary and Historical Aspects of the Burden of Malaria," 566; Stevenson and Riley, "Innate Immunity to Malaria," 169.

89 Carter and Mendis, "Evolutionary and Historical Aspects of the Burden of Malaria," 567.

90 Stevenson and Riley, "Innate Immunity to Malaria," 172.

91 The length of time required is not clear, but can be measured in thousands of years at least. See Carter and Mendis, "Evolutionary and Historical Aspects of the Burden of Malaria," 570-2, 573-4, 578

92 Carter and Mendis, "Evolutionary and Historical Aspects of the Burden of Malaria," 570.

93 Carter and Mendis, "Evolutionary and Historical Aspects of the Burden of Malaria," 571.

94 Carter and Mendis, "Evolutionary and Historical Aspects of the Burden of Malaria," 570-1.

95 Pliny, HN 20.71.184.

96 Pliny, HN 22.74.157, 23.61.114, 27.28.52.

97 Sallares, Malaria and Rome, 47.

98 Pliny, HN 27.28.52.

99 Angelo Celli, Malaria According to the New Researches, trans. John Joseph Eyre (London: Longmans, Green, 1901), 204, 207.

100 Varro, R.R. 1.12.3, Vitruvius 1.4.1, Sallares, Malaria and Rome, 57.

101 Columella, R.R. 1.5.6, Sallares, Malaria and Rome, 61.

102 Pliny, N.H. 18.7.33, Sallares, Malaria and Rome, 63.

103 Sallares, Malaria and Rome, 95.

104 Personal experience.

105 Siân E. Clarke, Claus Bøgh, Richard C. Brown, Margaret Pinder, Gijs E. L. Walraven, and Steve W. Lindsay, "Do Untreated Bednets Protect against Malaria?" Transactions of the Royal Society of Tropical Medicine and Hygiene 95 (2001): 457.

106 Clarke et al., “Do Untreated Bednets Protect against Malaria?" 457-8; 460-1.

107 "A Cautionary Tale: Pregnancy, Travel and Malaria," Centers for Disease Control and Prevention. http://www.cdc.gov/malaria/stories/malaria_travel_pregnancy.html reviewed and updated Feb. 2010

108 Christopher J. M. Whitty, Sally Edmonds, and Theonest K. Mutabingwa, "Malaria in Pregnancy," BJOG: An International Journal of Obstetrics and Gynaecology 122, no. 9 (September 2005): 1189.

109 Hollier et al, "Malaria in Pregnancy," 45.

110 Nafissatou Diagne, Christophe Rogier, Cheikh S. Sokhna, Adama Tall, Didier Fontenille, Christian Roussilhon, André Spiegel and Jean-François Trape, "Increased Susceptibility to Malaria during the early Postpartum Period," The New England Journal of Medicine 343, no. 9 (31 August 2000): 598.

111 Whitty et al, "Malaria in Pregnancy," 1189.

112 Sallares, Malaria and Rome, 67-8.

113 Asmus Hammerich, Oona M. R. Campbell, and Daniel Chandramohan, "Unstable Malaria Transmission and Maternal Mortality_Experience from Rwanda," Tropical Medicine and International Health 70, no. 7 (July 2002): 573.

114 Hammerich et al, "Unstable Malaria Transmission and Maternal Mortality," 574, with Table 1, 575 .

115 Whitty et al, "Malaria in Pregnancy," 1190, 1193.

116 Sallares, Malaria and Rome, 125-6.

117 Whitty et al, "Malaria in Pregnancy," 1189. See also Archna Sharma and Uma Khanduri, "How Benign is Benign Tertiary Malaria?" Journal of Vector Borne Diseases 46 (June 2009): 142, 143.

118 Sallares, Malaria and Rome, 126. 
119 Hollier et al, "Malaria in Pregnancy," 45.

120 Whitty et al, "Malaria in Pregnancy," 1193.

121 Burch, Taking the Medicine, 5. 